\title{
Abuses and Distortions in Emotional Processes as Risk Factors for Parricide
}

\author{
Ignazio Grattagliano ${ }^{1, *}$, Romy Greco ${ }^{2}$, Giancarlo Di Vella ${ }^{3}$, Grazia Maria Corbi ${ }^{4}$, Carlo Pietro \\ Campobasso $^{4}$, Maria Carolina Romanelli ${ }^{5}$, Alessio Ostuni ${ }^{5}$, Nicola Petruzzelli ${ }^{6}$, Valeria \\ Brunetti $^{7}$ and Rosalinda Cassibba ${ }^{8}$
}

\author{
${ }^{1}$ Section of Criminology, University "A. Moro" of Bari, Italy \\ ${ }^{2}$ Psychologist and Psychotherapist, Adjunct Professor of Social Psychology at the University LUMSA, Taranto \\ - EDAS (Ente Diocesano Apostolato Sociale, Faculty of Educational Sciences), Italy \\ ${ }^{3}$ Institute of Legal Medicine, University of Turin, Italy \\ ${ }^{4}$ Department of Medicine and Health Science, University of Molise, Italy \\ ${ }^{5}$ Medical Doctor, Trainee in Legal Medicine, University "A. Moro" of Bari, Italy \\ ${ }^{6}$ Juvenile Penal Institute "N. Fornelli" of Bari, Italy \\ ${ }^{7}$ Psychologist \\ ${ }^{8}$ Department of Educational Sciences, Psychology and Communication, University "A. Moro" of Bari, Italy
}

\begin{abstract}
Parricide is a rare case of murder having a strong emotional impact on public opinion, especially when it is heinous and perpetrated by minors. Based on the analysis of the judicial files archived at the Minor Penal Institute "N. Fornelli" of Bari, the authors will report three impressive cases perpetrated by minors, by focusing on their emotional features. Differences between the crimes of parricide committed by adults and minors will be highlighted, by analyzing the peculiar relations between the problems underlying parricide and the role played by abuses and maltreatments experienced by minors perpetrating such crime. In particular, attention will be paid to the emotional processes aroused in minor parricide offenders.
\end{abstract}

Keywords: Parricide, abuses, emotions, violence, shame, anger.

\section{INTRODUCTION}

Parricide is the murder of one's parent, either a biological or an acquired one, and it comprises patricide, that is the murder of one's father, matricide, which is the murder of one's mother and the case of double parricide, when both parents are killed (Heide 1992; Hillbrand et al. 1999; Shon and Targonski 2003; Campobasso, Laviola et al. 2015).

It is a rare case of crime and it represents a minor percentage of the voluntary murders: in Europe and North America it has an incidence of about 2-4\%, with a prevalence of patricides (Bourget, Gagné, and Labelle 2007; Ewing 1997; Heide and Petee 2007; Hillbrand et al. 1999; Marleau, Millaud, and Auclair 2001; Marleau, Millaud, and Auclair 2003; Weisman and Sharma 1997), while in Italy the estimate does not reach $3 \%, 59 \%$ of which are matricides (EURES-ANSA 2010).

In most of the cases, the murder takes place in the family home, and the perpetrator and the victim are

*Address correspondence to this author at the Section of Criminology, University "A. Moro" of Bari, Italy; Tel: +39080-5478364;

Fax: +39080-5478248; E-mail: ignazio.grattagliano@uniba.it usually living together (Bourget et al. 2007; Heide 1993). The parricide perpetrated by minors rarely happens during violent conflicts; more likely it takes place when the parent is defenceless, or in conditions in which the victim has a low vigilance threshold. Moreover, the aggressor-child acts in a cool and calculating manner (Mones 1991).

From a criminological perspective, the perpetrator of such crime is more frequently the male child (the proportion son - daughter is $15: 1$ ), the father is likely to be the victim more than the mother (the proportion father - mother is 2:1) and the place of the murder is the parents' home. Usually, there are no accomplices, and the perpetrators, in pray of an impulsive reaction of the moment, turn to ordinary objects in the home (the so-called occasional weapons, such as blunt or sharp instruments), or alternatively to firearm; rarely, they use asphyxial manoeuvring. Lastly, the murderer is conscious of his responsibilities and does not try to run away after the crime (Hillbrand et al. 1999).

The prevalence of male gender among the perpetrators of crimes justifies why most of the parricides are perpetrated by males, while the ethnic 
background does not seem to play a role (Ewing 2013; Greco, Curci, and Grattagliano 2009; Hart and Helms 2003; Heide 1993; Heide and Petee 2007; Hillbrand et al. 1999; Marleau, Millaud, and Auclair 2003; Marvelli 2013). Marleau et al. (2003) reported the features of $90 \%$ of the male parricides which took place in Canada between 1961 and 1989. The modality characterizing the murder is often violent and bloody, many times accompanied by "overkilling" (Bourget et al. 2007). Because they are physically inferior to their parent, male adolescents prefer firearms (Hart and Helms 2003; Heide 1993), while females knives (Walsh, Frienert, and Crowder 2008).

The reasons driving to parricide as well as the characteristics of the crime vary depending on the perpetrator's age (Cooke 2001). Most of the adolescent parricide offenders act in reaction to experiences of physical or sexual abuses perpetrated by their parents (Grattagliano 2014; Grattagliano et al. 2014; Lisi et al. 2012; Lisi et al. 2013). Instead, adult aggressors, usually between thirty and forty years of age, are psychiatric patients who commit the crime as a consequence of their mental illness (Heide 1992; Heide 1993; Heide 1994; Hillbrand et al. 1999; Marleau et al. 2003; Millaud, Auclair, and Meunier 1996; Shon and Targonski 2003; Weisman and Sharma 1997), as well as of precipitant factors, such as alcohol or drug abuse or the death of a significant other (Millaud et al. 1996). These perpetrators are mostly single, unemployed or with part-time jobs and live together with the victim (Millaud et al. 1996); they also have poor social relationships or are engaged in very few extra-familiar activities (Cooke 2001). Because of their health problems and inability to achieve self-sufficiency, they are forced to live together with their family members (Cooke 2001; Hillbrand et al. 1999; Millaud et al. 1996) and to depend financially from them: in this context conflictual relationships appear inevitable (Cooke 2001). Moreover, adult perpetrators affected by severe mental illness murder most frequently their mother, while adolescents address their fathers (Bourget et al. 2007; Hillbrand et al. 1999; Millaud et al. 1996; Weisman and Sharma 1997).

To get to the point to murder a parent, who is also a loved person, it is necessary to feel, besides affection, a deep feeling of hate against him/her (Grattagliano et al. 2012; Margari et al. 2013; Oliviero Ferrarsi and Giorda 1995), which justifies both the absence of accomplices and the cruelty of the crime. The murder of a parent is to be interpreted as the destruction of an insane reference model as well as of a despicable part of the self (De Leo and Bollea 1988).

The hate against a parent can arise from the parent's incapacity or rejection to satisfy the child's basic needs or, alternatively, from the parent being excessively demanding towards "powerless" children (Cooke 2001). The wish to kill a parent leads to a catastrophic conflict between the dependency from the family and the current desire of autonomy (Millaud et al. 1996).

Hereby, the authors report three cases of parricide committed by adolescents, recruited from the files of the Juvenile Penal Institute "N. Fornelli" of Bari.

\section{CASE 1}

This is a 15-year old boy, firstborn of three children and the only male, who lived in his family, together with his father (a 40 year-old blacksmith, currently receiving redundancy payments), the mother (a 30-old woman, employed in a cleaning company) and the two sisters (10 and 12 years old respectively). Within the family, there were many conflicts between the parents, who alternated between separations and reconciliations, to the point that it became necessary for the Social Services to monitor the situation. Often the children were involved in violent arguments between the parents and were instigated by their mother, who was perceived as the main caregiver, to go against their father.

In such context, the boy would use a defensive mechanism based on the detachment and the repression of the events: on one side, he did not appear particularly distressed towards his father (with whom he had also lived together); on the other side, he clearly remembered his father's aggressive attacks.

With the complicity and the incitement of his mother, the boy planned the patricide (in the last months before the crime he had become introverted and reserved towards the social workers) which he perpetrated with the aid of a butcher's hook and some acid.

During the detention, the minor displayed indifference to both of his parental figures and the events that had occurred, and seemed not to be aware of the consequences of his act; indeed he was hoping that his family could achieve a new balance. During the stay at the juvenile penal institute, the boy appeared introverted and closed with his peers, but at the same time available to establish a relationship with the adults 
figures, as he displayed appreciation for the support he was receiving and interest in the occupational and recreational activities that he was encouraged to take part in.

\section{CASE 2}

This is a 15-years-old boy, who used to live with his parents and brothers (the father was 45 years old; his mother was a 40-years-old housewife; a 23 years-old unemployed brother, a 22 year-old sister with a severe mental retardation and a 10 years-old sister attending elementary school).

The father was described as authoritarian, disinterested in the family and violent; the man used to have two mistresses and at the time of the murder he was under house arrest because of sexual harassments against a minor girl. Lately, the man was showing an unhealthy interest for the two dominating mistresses and a will to annihilate the female family members.

On the contrary, the mother was subdued and was used to suffer the harsh treatment of the husband (with the consequence of exposing also her daughters to it) and lived in the terror of violence.

The boy had not completed his education because of his father's interference and had recently interrupted an affective relationship with a girl in order to protect her against the violent offences of his father. Moreover, he had recently been forced to face alone, without the support of his older brother, the increasing aggressiveness of his father. This situation had lead him to plan the murder, perpetrated with a sawn-off shotgun, in order to save himself, his sisters and his mother from the violence they had experienced. The parricide was experienced by the boy also as an attempt to affirm his anti-male chauvinism, in contrast of that of his father.

After the murder, the boy confessed the crime and was then sent in preventive custody to a juvenile penal institute because of the possession of a firearm and premeditated murder.

\section{CASE 3}

The patricide is a 17 years-old girl who murdered her father, an ex-mason of 36 years old. The family included also the mother of 35 years old, employed in a cleaning company, and two minor brothers of 11 and 4 years old.
The girl had grown up in the North of Italy, and had experienced poor social relationships and school achievement. At 14 years old, she had moved together with her family to the South of Italy, in the native place of her parents and she had experienced this change in a negative way. Afterwards, she gave up her studies and started to work with her mother, because her father had prohibited her to attend a professional school.

The girl was involved in a pathological relationship with her mother, as it appeared to be a peer-like more than a parent-child relationship. She identified her mother as her main attachment figure, whereas she perceived her father as a violent, nervous, possessive and jealous person. The family environment was described as tense and not much quiet. Moreover, the minor had started a romantic relationship with a boy, but she had interrupted it because she suffered from not having enough freedom, as she perceived the boy similar to her father.

With the complicity of her mother and of her maternal grandmother, the adolescent girl at first poisoned the father with benzodiapezine, and then she strangled him with a nylon string.

During the detention, the girl appeared calm, respectful of the rules, emotionally regulated but concerned about the consequences of the crime she had committed.

\section{DISCUSSION}

As it is illustrated in the three cases, the crime of parricide perpetrated by adolescents arises almost always from the need to end repeated experiences of abuse and maltreatment. The sense of despair pushes these young victims to react against their abusing parents in order to defend themselves and the other weak family members (Heide 1992; Mones 1991). Additionally, the presence of psychiatric illnesses and juvenile antisocial attitudes can favor the perpetration of this crime (Ewing 1990; Heide 1996).

Given these premises, minor perpetrators of parricide can be differentiated in: 1) adolescents suffering of severe mental illnesses, 2) antisocial adolescents and 3) abused adolescents (Hart and Helms 2002).

Among the first group, the contact with reality is lost and the parricide is committed being a prey to deliriums and hallucinations. There is no awareness of the illness and it may happen that the delirium is directed against more than one person (Hart and Helms 2002). 
The second group, instead, comprises adolescents with conduct disorder (who may develop later on an antisocial personality disorder), rebellious and aggressive against people and animals, and lacking of regret for their actions. In these cases, the parricide is the expression of the adolescents' aggressiveness and delinquency and the psychological dynamics characterizing the parricide are different from those that occur in the other cases of parricide (Cooke 2001). The poor coping strategies of these adolescents in facing stressful events can lead them to be unpredictable. Thus, scarcely relevant episodes, as for example when the parents do not allow them to go out with their friends, may cause them to explode (Hart and Helms 2002).

The third group is the most frequent one, and it includes minors who conceive the murder of the abusing figure as the only way to escape from years of experiencing physical and psychological abuse (Hart and Helms 2002; Hillbrand et al. 1999). The parricides belonging to this group usually have clear records and have grown up in violent families, characterized by alcohol abuse and easy access to arms. These minors appear unable to tolerate the family conditions, have poor social relationships and can easily lose control under stressful conditions. The crime is committed during a dissociative state and it gives a sense of relief to the perpetrator (Cooke 2001).

This last category of parricide has been related to the Battered Child Syndrome (BCS), that is a clinical condition in which prolonged abuses perpetrated by a biological or adoptive parent against a child (Kempe et al. 1962) cause physical and psychological effects (Hart and Helms 2002; Scorca et al. 2013). In this view, the murder is conceived as the minor's self-defense act. This kind of defense is what makes the difference between the parricide perpetrated by adolescents and other types of crimes perpetrated by adolescents as well as cases of parricides committed by adults.

In the forensic domain, the tendency to use the BCS to claim for self-defense in cases of parricide derives from the analogy between this syndrome and the Battered Women Syndrome (BWS). Nevertheless, this similarity is to date undemonstrated as there are many features characterizing the first but not the second, although there are also some similarities between the two conditions.

In the BCS, as well as in the BWS, the victim usually develops an indissoluble dependency from the abusing figure because of the fear to exacerbate the violence in case the relationship is interrupted. Moreover, the minors affected by this syndrome typically display "learned helplessness" and "hypervigilance" associated with the Post-Traumatic Stress Disorder (PTSD). Learned helplessness is defined as the condition in which the adolescents, because of the prolonged experiences of abuse, develop the belief that the violence they undergo is inevitable and that nobody can help them (Hart and Helms 2002). These individuals tend to refrain from sharing with others what occurs in their home because they are threatened by the abusing figures and convinced that what happens in their families is a private affair, but also because those with whom they share these events often do not intervene to protect them, event that reinforces their feeling of helplessness (Heide 1992). The "hypervigilance" implies an increased attention towards the surrounding environment and to signals of threat. Over time, this monitoring activity becomes a routine and the minor learns to recognize them and then to anticipate the signals of the phase preceding the aggression in order to avert the abuse or to defend him/herself.

While maltreated women are involved in recurrent violent circles (Walker 1984), in the BCS these circles of violence do not occur. Moreover, maltreated minors experience a sense of humiliation and shame for the recurrent abuses, as they consider them undeserved; the fantasies induced by the feeling of shame seem to favor a mental state of revenge (Lansky 2005) and an illusion of being powerful which contrast dramatically with the victim's experience of being actually powerlessness (Horowitz 2007). When this mental state occurs, the abused minor develops the belief that the murder of the parent is a well justified act and proportional to the humiliations he/she has experienced. The minors may concentrate themselves on the idea to take the law into their own hands more than on the consequences of the act. On these premises, it becomes possible to understand the quietness that minors show before and after the murder, the lack of remorse, as well as the dissociation that occurs at the time of the murder which had origin in reaction to the first episodes of maltreatment (Stein 2007).

From a forensic standpoint, in order to adhere to the argument that parricide is a kind of "self-defense", it is necessary to highlight not only the learned helplessness and the hyper-vigilance in the abused children, but also the recurrence of an imminent threat of death for the minor; in other words, the minor's 
tendency to recognize signal of impending violence, although in many cases these stimuli are not clearly threatening.

\section{THE ROLE OF THE EMOTIONAL PROCESSES}

The mediation of the emotional processes explains why abuse can lead to different outcomes among maltreated individuals. Among minors, a central role is played by shame, humiliation and anger, together with specific representations of the self (Lewis 1971; Tangney and Dearing 2003). Maltreated children, especially those abused, characteristically experience shame (Loader 1998); moreover, they have parents with a negative or an authoritarian parental style (Alessandri and Lewis 1993; Alessandri and Lewis 1996; Belsky and Domitrovich 1997; Lewis 1992; Margari et al. 2013; Mills 2003; Stuewig and McCloskey 2005).

Children who are systematically punished, criticized, rejected or neglected by their caregivers, develop a representation of the self as a wrong, undesired, bad and unworthy to be loved person (Burhans and Dweck 1995). These beliefs about the self elicit shame (Lewis 1992) and lead these children, who continue over time to be maltreated, to develop emotional processes different from those of not maltreated ones and which can be different whether the victim is a boy or a girl (Alessandri and Lewis 1996). Indeed, Mills (2003) highlighted that preschool girls are more likely to experience shame when they experience an authoritarian parental style, associated with physical punishments (Frias-Armenta and McCloskey 1998). With respect to older minor, severe parenting at age nine is predictive of parental rejection at 15 years old, which is associated with an increased propensity to experience shame at the same age (Stuewig and McCloskey 2005).

Moreover, abused preschool children are more at risk to develop later on behavioral problems, compared to those who are victims of maltreatment at later ages (Keiley et al. 2001). Similarly, physical abuse is predictive of externalizing problems in preschool age, but not in school age (Manly et al. 2001).

Shame, guilt and pride belong to the same class of emotions, the so-called self-evaluative emotions (Darwin 1865) and start to emerge between two and a half - three years of age, thanks' to self-consciousness (Lewis et al. 1989; Lewis, Alessandri and Sullivan 1992; Stipek, Recchia and McClintic 1992). Children develop usually a basic understanding of behavioral rules and standards during preschool age (Barrett and Campos 1987; Lewis 1995). By four years old, children already display consistent individual differences in the quality and quantity of their negative emotional reaction in facing a failure (Alessandri and Lewis 1996; Dweck, Chiu and Hong 1995). Compared to the not maltreated ones, physically abused children, but not the neglected ones, have more negative representations of the self (Toth et al. 1997) and are more likely to experience self-evaluative emotions in reaction to a failure, because of the biases in their negative beliefs about the self, their abilities and their personal value.

The increased propensity to experience shame following repeated experiences of maltreatment, is associated with a set of emotional and behavioral consequences: both minors and adults have been reported to be more incline to display anger and sadness, together with internalizing and externalizing behavioral problems (Andrews et al. 2000; Bryceland and Strayer 1999; Dutton, van Ginkel, and Starzomski 1995; Ferguson et al. 2000; Harper and Arias 2004; Mills 2003; Stuewig and McCloskey 2005; Tangney 1991; Tangney et al. 1991; Tangney, Wagner, and Gramzow 1992; Tangney et al. 1996).

Shame can be elaborated into anger, as the externalization of a fault, or in depression, as a consequence of the internalization of the fault (Lewis 1971; Lewis 1987; Lewis 1992; Miller 1985). Therefore, the emotion of shame could act as a mediator in the relation between maltreatments and anger, as well as in that between maltreatments and depression, and the prevalence of one or the other outcome may depend upon whether the victim attributes the fault towards the external world or towards the self.

Lastly, although there are no clear evidence suggesting that maltreatment leads to specific developmental difficulties (Crittenden, Claussen, and Sugarman 1994; Kinard 2004), it has been consistently reported that physical abuse is associated with shame, anger and externalizing problems (Bousha and Twentyman 1984; Elliot et al. 1995; Hoffman-Plotkin and Twentyman 1984; Loader 1998; Manly et al. 2001), whereas neglect to internalizing ones (Fantuzzo et al. 1998; Hoffman-Plotkin and Twentyman 1984; Lynch and Cicchetti 1998; Manly et al. 2001). Although anger can have an adaptive function, when it occurs together with shame it becomes dysfunctional (Lewis 1971; Lewis 1993; Morrison 1989; Retzinger 1987). Anger is therefore an emotion typical of victims of maltreatment, 
as they react to the shame and the humiliation following the experience of violence, with rage, and end up in the so-called shame-rage spiral (Sheff 1987).

\section{CONCLUSIONS}

Affective deprivation, brutality and constraints from one or both parents may cause the child to develop a personality with disharmonious or immature features. Imbalances and alterations in the emotional domain can compromise consequently the emergence of a mature ego, which usually allows children to be conscious of the consequences of their own and others actions and sufficiently sensitive.

In light of what has been reported above, the parricide perpetrated by minor offenders, who were abused by their parents, can be interpreted as the effect of multiple risk factors: the early identification of these factors both on a clinical and on a criminological/forensic standpoint can prevent the desire for revenge to achieve a concrete expression in the tragic and irreversible event of the parent's murder.

\section{ACKNOWLEDGEMENTS}

The authors express appreciation to the management of the Centre of Minor Justice and, specifically to the Directors Doct. Francesca Perrini and Pietro Sansò, for their sensitivity and availability in allowing the access to the judicial files related to the crimes. Moreover, they express appreciation to the Juvenile Penal Institute "N. Fornelli" of Bari, and particularly to its Director Doct. Nicola Petruzzelli, for giving the permission to collect the data of the minors who perpetrated the crimes reported in this paper. Lastly, they thank the workers of the First Reception Centre of the same Institute for their collaboration.

\section{REFERENCES}

Alessandri, S.M., Lewis, M. 1993. Parental Evaluation and Its Relation to Shame and Pride in Young Children. Sex Roles, 29: $335-343$.

http://dx.doi.org/10.1007/BF00289427

Alessandri, S.M., Lewis, M. 1996. Differences in Pride and Shame in Maltreated and Nonmaltreated Preschoolers. Child Development, 67: 1857-1869. http://dx.doi.org/10.2307/1131736

Andrews, B., Brewin, C.R., Rose, S., Kirk, M. 2000. Predicting PTSD Symptoms in Victims of Violent Crime: The Role of Shame, Anger, and Childhood Abuse. Journal of Abnormal Psychology, 109: 69-73. http://dx.doi.org/10.1037/0021-843X.109.1.69

Barrett, K.C., Campos, J.J. 1987. Perspectives on Emotional Development. A Functionalist Approach to Emotions. In: Osofsky J.D., editor, Handbook of Infant Development (pp. 555-578). New York: Wiley.
Belsky, J., Domitrovich, C. 1997. Temperament and Parenting Antecedents of Individual Difference in Three-year-old Boys' Pride and Shame Reactions. Child Development, 68: 456466.

http://dx.doi.org/10.2307/1131671

Bourget, D., Gagnè, P., Labelle, M. E. 2007. Parricide: a Comparative Study of Matricide Versus Patricide. Journal of the American Academy of Psychiatry and the Law, 35: 30612.

Bousha, D., Twentyman, C. 1984. Mother-child Interactional Style in Abuse, Neglect, and Control Groups: Naturalistic Observations in the Home. Journal of Abnormal Psychology, 93: 106-114. http://dx.doi.org/10.1037/0021-843X.93.1.106

Bryceland, C., Strayer, J. 1999. Shame and Guilt: A Functionalist Reconceptualization Applied to Adaptive-maladaptive Continua. Poster presented at the meeting of the Society for Research in Child Development, Albuquerque, New Mexico.

Burhans, K.K., Dweck, C.S. 1995. Helplessness in Early Childhood: The Role of Contingent Worth. Child Development, 66: 17191738. http://dx.doi.org/10.2307/1131906

Campobasso C.P., Laviola D, Grattagliano I, Strada L, Dell'Erba A. Undetected patricide: Inaccuracy of cause of death determination without an autopsy, J Forensic Leg Med 34 (2015) 67 e72.

Cooke, G. 2001. Parricide. Journal of threat assessment, 1: 35-44. http://dx.doi.org/10.1300/J177v01n01 04

Crittenden, P.M., Claussen, A.H., Sugarman, D.B. 1994. Physical and Psychological Maltreatment in Middle Childhood and Adolescence. Development and Psychopathology, 6: 145164.

http://dx.doi.org/10.1017/S0954579400005927

Darwin, C. 1865. The Expression of Emotion in Animals and Man. Chicago: University of Chicago Press. Original work published 1872.

De Leo, G., Bollea, G. 1988. II Parricidio in Età Evolutiva [The Parricide in the Developmental Age]. In F. Ferracuti (a cura di), Trattato di Criminologia, Medicina Criminologica e Psichiatria Forense [Treatise of Criminology, Medicine and Forensic Psychiatry](pp.131-148), Vol.VII, Milano: Giuffrè Editore,

Dutton, D.G., van Ginkel, C., Starzomski, A. 1995. The Role of Shame and Guilt in the Intergenerational Transmission of Abusiveness. Violence and Victims, 10: 121-131.

Dweck, C.S., Chiu, C., Hong, Y. 1995. Implicit Theories and Their Role in Judgments and Reactions: A World From Two Perspectives. Psychological Inquiry, 6: 267-285. http://dx.doi.org/10.1207/s15327965pli0604 1

Elliott, D.M., Briere, J., McNeil, D., Cox, J., Bauman, D. 1995 Multivariate Impacts of Sexual Molestation, Physical Abuse and Neglect in a Forensic Sample. Paper presented at the Fourth International Family Violence Research Conference. Durham, New Hampshire.

EURES-ANSA 2010. L'Omicidio Volontario in Italia, Rapporto [Intentional Homicide in Italy. A report].

Ewing, C.P. 1990. Kids Who Kill. Lexington, MA: Lexington Books.

Ewing, C.P. 1997. Fatal Families: The Dynamics of Intrafamilial Homicide. California: Sage Publications.

Ewing, C.P. 2001. Parricide. In G. F. Pinard and L. Pagani (a cura di), Clinical Assessment of Dangerousness (181-194). New York: Cambridge University Press.

Fantuzzo, J.W., Weiss, A.D., Atkins, M., Meyers, R., Noone, M 1998. A Contextually Relevant Assessment of the Impact of Child Maltreatment on the Social Competencies of Lowincome Urban Children. Journal of the Academy of Child and Adolescent Psychiatry, 37: 1201-1208. http://dx.doi.org/10.1097/00004583-199811000-00021 
Ferguson, T.J., Stegge, H., Eyre, H.L., Vollmer, R., Ashbaker, M. 2000. Context Effects and the (Mal)adaptive Nature of Guilt and Shame in Children. Genetic, Social, and General Psychology Monographs, 126: 319-345.

Frias-Armenta, M., McCloskey, L.A. 1998. Determinants of Harsh Parenting in Mexico. Journal of Abnormal Child Psychology, 26: $129-139$. http://dx.doi.org/10.1023/A:1022621922331

Grattagliano, I. 2014. PAS e Metodologia Peritale [PAS and Expert Methodology]. Psicologia Clinica dello Sviluppo, 17: 340-344.

Grattagliano I., Cassibba R., Greco R., Laudisa A., Torres A., Mastromarino A. 2012. Stalking: Old Behaviour New Crime. Reflections on 11 Cases Assessed in the Judicial District of Bari. Rivista di Psichiatria, 47: 65-72.

Grattagliano, I., Corbi, G., Catanesi R., Ferrara, N., Lisi, A., Campobasso C.P. 2014. False Accusations of Sexual Abuse as a Mean of Revenge in Couple Disputes. Clinic Therapeutic, 165: 119-124.

Greco, R., Curci, A., Grattagliano, I. 2009. Juvenile Criminality: General Strain Theory and the Reactive-Proactive Aggression Trait. Rivista di Psichiatria, 44: 328-336.

Harper, F.W.K., Arias, I. 2004. The Role of Shame in Predicting Adult Anger and Depressive Symptoms Among Victims of Child Psychological Maltreatment. Journal of Family Violence, 19: 367-375.

http://dx.doi.org/10.1007/s10896-004-0681-x

Hart, J.L., Helms, J.L. 2002. Factors of Parricide: Allowance of the Use of Battered Child Syndrome as a Defense. Aggression and Violent Behavior, 267: 1-13.

Hart, J.L., Helms, J.L. 2003. Factors of Parricide: Allowance of the Use of Battered Child Syndrome as a Defense. Aggression and Violent Behavior, 8: 671-83. http://dx.doi.org/10.1016/S1359-1789(02)00103-9

Heide, K.M. 1992. Why Kids Kill Parents: Child Abuse and Adolescent Homicide. Columbus, Ohio: Ohio State University Press (Cloth); (1995) Thousand Oaks, Sage Publications (paperback).

Heide, K.M. 1993. Weapons Used by Juveniles and Adults to Kill Parents. Behavioral Sciences and the Law, 11: 397-405. http://dx.doi.org/10.1002/bsl.2370110407

Heide, K.M. 1994. Evidence of Child Maltreatment Among Adolescent Parricide Offenders. International Journal of Offender Therapy and Comparative Criminology, 38: 151162. http://dx.doi.org/10.1177/0306624X9403800207

Heide, K.M. 1996. Why Kids Keep Killing: The Correlates, Causes, and Challenge of Juvenile Homicide. Stanford Law and Policy Review, 7: 43-49.

Heide, K.M., Petee, T.A. 2007. Parricide: an Empirical Analysis of 24 Years of U.S. Data. Journal of Interpersonal Violence, 22: 1382-99. http://dx.doi.org/10.1177/0886260507305526

Hillbrand, M., Alexandre, J.W., Young, J.L., Spitz, R.T. 1999. Parricide: Characteristics of Offenders and Victims, Legal Factors, and Treatment Issues. Aggression and Violent Behavior, 4: 172-190.

Hoffman-Plotkin, D., Twentyman, C.T. 1984. A Multimodal Assessment of Behavioral and Cognitive Deficits in Abused and Neglected Preschoolers. Child Development, 55: 794802.

http://dx.doi.org/10.2307/1130130

Horowitz, M.J. 2007. Understanding and Ameliorating Revenge Fantasies in Psychotherapy. American Journal of Psychiatry, 164: 24-7. http://dx.doi.org/10.1176/appi.ajp.164.1.24

Keiley, M.K., Howe, T.R., Dodge, K.A., Bates, J.E., Pettit, G.S. 2001. The Timing of Child Physical Maltreatment: A Cross-domain Growth Analysis of Impact on Adolescent Externalizing and
Internalizing Problems. Developmental Psychopathology, 13: 891- 912.

Kempe, C.H., Silverman, F.N., Steele, B.F., Droegemuller, W., Silver, H.K. 1962. The Battered Child Syndrome. Journal of the American Medical Association, 181: 17-24. http://dx.doi.org/10.1001/jama.1962.03050270019004

Kinard, E.M. 2004. Methodological Issues in Assessing the Effects of Maltreatment Characteristics on Behavioral Adjustment in Maltreated Children. Journal of Family Violence, 19: 303318.

\section{http://dx.doi.org/10.1023/B:JOFV.0000042080.98027.ae}

Lansky, M. 2005. The Impossibility of Forgiveness: Shame Fantasies as Investigators of Vengefulness in Euripides' Medea. Journal of American Psychoanalitic Association, 53: 437-464. http://dx.doi.org/10.1177/00030651050530021701

Lewis, H.B. 1971. Shame and Guilt in Neurosis. New York: International Universities Press.

Lewis, H.B. 1987. The Role of Shame in Depression Over the Life Span. In: Lewis, H.B., editor, The Role of Shame in Symptom Formation (pp. 29-50). Hillsdale, NJ: Lawrence Erlbaum.

Lewis, M. 1992. Shame: The Exposed Self. New York: The Free Press.

Lewis, M. 1993. The Development of Anger and Rage. In: Glick, R.A., Roofe, S.P., editors. Rage Power and Aggression: The Role of Affect in Motivation, Development, and Adaptation (pp. 148-168). New Haven: Yale University Press.

Lewis, M. 1995. Self-Conscious Emotions. American Scientist, 83: 68-78.

Lewis, M., Alessandri, S.M., Sullivan, M.W. 1992. Differences in Pride and Shame as a Function of Children's Gender and Task Difficulty. Child Development, 63: 630-638. http://dx.doi.org/10.2307/1131351

Lewis, M., Sullivan, M.W., Stanger, C., Weiss, M. 1989. Selfdevelopment and Self-conscious Emotions. Child Development, 25: 439-443. http://dx.doi.org/10.2307/1131080

Lisi, A., Stallone, V., Tomasino, M.G., Affatati V., Dimastromatteo C., Grattagliano, I. 2013. Uselfulness and Limits of the Family Drawing Test, in the Evaluation of Child Sexual Abuse in Expert Testimony: A Field Survey. Maltrattamento ed Abuso All'infanzia, 15: 81-96.

Lisi A., Stallone, V., Tomasino, M.G., Affatati V., Zelano C., Grattagliano, I. 2012. The Utility and Limitations of the Human Figure Drawing Test in the Evaluation of the Child Abuse's Cases in Expert Testimony Circles. Psicologia Clinica dello Sviluppo, 16: 421-439.

Loader, P. 1998. Such a Shame-A Consideration of Shame and Shaming Mechanisms in Families. Child Abuse Review, 7: 44-57.

http://dx.doi.org/10.1002/(SICI)10990852(199801/02)7:1<44::AID-CAR334>3.0.CO;2-7

Lynch, M., Cicchetti, D. 1998. An Ecological-Transactional Analysis of Children and Contexts: The Longitudinal Interplay Among Child Maltreatment, Community Violence, and Children's Symptomatology. Development and Psychopathology, 10: 235-257. http://dx.doi.org/10.1017/S095457949800159X

Manly, J.T., Kim, J.E., Rogosch, F.A., Cicchetti, D. 2001. Dimensions of Child Maltreatment and Children's Adjustment: Contributions of Developmental Timing and Subtype. Development and Psychopathology, 13: 759-782.

Margari, L., Pinto, F., Lafortezza, M.E., Lecce, P.A., Craig, F., Grattagliano, I., Zagaria, G., Margari, F. 2013. Mental Health in Migrant Schoolchildren in Italy: Teacher-Reported Behavior and Emotional Problems. Neuropsychiatric Disease and Treatment, 9: 231-241.

http://dx.doi.org/10.2147/NDT.S37829 
Marleau, J. D., Millaud, F., Auclair, N. 2001. Parricide Commis Par des Femmes: Synthèse de la littérature. Revue québécoise de psychologie, 22 : 91-102.

Marleau, J.D., Millaud, F., Auclair, N. 2003. A Comparison of Parricide and Attempted Parricide: A Study of 39 Psychotic Adults. International Journal of Law and Psychiatry, 26: 26979. http://dx.doi.org/10.1016/S0160-2527(03)00037-2

Marvelli, E., Grattagliano, I., Aventagiato, L., Gagliano, C.R. 2013. Substance Use and Victimization in Violent Assaults, Clinica Terapeutica, 164: 239-244.

Millaud, F., Auclair, N., Meunier, D. 1996. Parricide and Mental Illness. A Study of 12 Cases. International Journal of Law and Psychiatry, 19: 173-182. http://dx.doi.org/10.1016/0160-2527(96)00003-9

Miller, S. 1985. The Shame Experience. Hillsdale, NJ: Lawrence Erlbaum.

Mills, R.S.L. 2003. Possible Antecedents and Developmental Implications of Shame in Young Girls. Infant and Child Development, 12: 329-349. http://dx.doi.org/10.1002/icd.308

Mones, P. 1991. When a Child Kills: Abused Children Who Kill Their Parents. New York: Pocket Books.

Morrison, A.P. 1989. Shame: The Underside of Narcissism. The Analytic Press.

Oliviero Ferrarsi, A., Giorda, G. 1995. Parricidio. Tipologia e Dinamiche Emotive di un Orrore [Parricide. Typology and Emotional Dynamics of a Horror]. Psicologia Contemporanea, 131: 18 - 25.

Retzinger, S.M. 1987. Resentment and Laughter: Video Studies of the Shame-rage Spiral. In: Lewis, H.B., editor, The Role of Shame in Symptom Formation (pp. 115-181). Hillsdale, NJ: Lawrence Erlbaum.

Scheff, T.J. 1987. The Shame-rage Spiral: A Case Study of an Interminable Quarrel. In: Lewis, H.B., editor, The Role of Shame in Symptom Formation (pp. 109-149). Hillsdale, NJ: Lawrence Erlbaum.

Scorca, A., Santoro, V., De Donno, A., Grattagliano, I., Tafuri, S., Introna, F. 2013. Early Childhood Caries (ECC) and Neglect in Child Care: Analysis of an Italian Sample. Clinica Terapeutica, 164, 365-371.

Shon, P.C., Targonski, J.R. 2003. Declining Trends in U.S. Parricides, 1976-1998: Testing the Freudian Assumptions. International Journal of Law and Psychiatry, 26: 387-402. http://dx.doi.org/10.1016/S0160-2527(03)00049-9
Stein, A. 2007. Prologue to Violence. Mahwah, NJ: The Analytic Press.

Stipek, D., Recchia, S., McClintic, S. 1992. Self-evaluation in Young Children. Monographs of the Society for Research in Child Development, 57, Serial No. 226.

Stuewig, J., McCloskey, L. 2005. The Relation of Child Maltreatment to Shame and Guilt Among Adolescents: Psychological Routes to Depression and Delinquency. Child Maltreatment, 10: 324-336. http://dx.doi.org/10.1177/1077559505279308

Tangney, J.P. 1991. Moral Affect: The Good, the Bad, and the Ugly. Journal of Personality and Social Psychology, 61: 598-607. http://dx.doi.org/10.1037/0022-3514.61.4.598

Tangney, J.P., Dearing, R.L. 2003. Shame and Guilt. New York: Guilford Press.

Tangney, J.P., Wagner, P.E., Burggraf, S.A., Gramzow, R.J., Fletcher, C. 1991. Children's Shame-proneness, but Not Guilt-proneness, is Related to Emotional and Behavioral Maladjustment. Poster presented at the meeting of the American Psychological Society; Washington, DC, June.

Tangney, J.P., Wagner, P., Gramzow, R. 1992. Proneness to Shame, Proneness to Guilt, and Psychopathology. Journal of Abnormal Psychology, 101: 469-478. http://dx.doi.org/10.1037/0021-843X.101.3.469

Tangney, J.P., Wagner, P.E., Hill-Barlow, D., Marschall, D.E., Gramzow, R. 1996. The Relation of Shame and Guilt to Constructive Versus Destructive Responses to Anger Across the Lifespan. Journal of Personality and Social Psychology, 70: 797-809. http://dx.doi.org/10.1037/0022-3514.70.4.797

Toth, S.L., Cicchetti, D., Macfie, J., Emde, R.N. 1997. Representations of Self and Other in the Narratives of Neglected, Physically Abused, and Sexually Abused Preschoolers. Development and Psychopathology, 9: 781796.

http://dx.doi.org/10.1017/S0954579497001430

Walker, L. 1984. The Battered Women Syndrome. New York: Springer.

Walsh, J., Frienert, J., Crowder, D. 2008. Innocence Lost: A GenderBased Study of Parricide Offender, Victim, and Incident Characteristics in a National Sample 1976-2003. Journal of Aggression, Maltreatment and Trauma, 16, 202-227. http://dx.doi.org/10.1080/10926770801921584

Weisman, A.M., Sharma, K.K. 1997. Forensic Analysis and Psycholegal Implications of Parricide and Attempted Parricide. Journal of Forensic Sciences, 42: 1107-1113.

\section{DOl: http://dx.doi.org/10.6000/1929-4409.2015.04.13}

(c) 2015 Grattagliano et al.; Licensee Lifescience Global.

This is an open access article licensed under the terms of the Creative Commons Attribution Non-Commercial License (http://creativecommons.org/licenses/by-nc/3.0/) which permits unrestricted, non-commercial use, distribution and reproduction in any medium, provided the work is properly cited. 